\title{
EXPERIENCES MATTER! LUXURY TOURISM CONSUMPTION PATTERNS AND MOTIVATION OF THE CZECH AFFLUENT SOCIETY
}

\author{
Markéta NOVOTNÁa , Josef KUNC ${ }^{a}$ \\ ${ }^{a}$ Faculty of Economics and Administration, Masaryk University, Lipová 41a, Brno 602 00, Czech \\ Republic, E-mail: marketa.novotna@econ.muni.cz,kunc@econ.muni.cz
}

Cite this article: Novotná, M., Kunc, J. (2019). Experience Matters! Luxury consumption patterns and motivation of the Czech affluent society. Deturope. 11(2), 121-142.

\begin{abstract}
The affluent society and its leisure lifestyle and luxury consumption can influence the future tourism trends. One key prerequisite shaping the future of luxury tourism is the shift in values from the material to the experiential purchases. It is related to the assumption that money spent on experiences can satisfy various people's needs. Moreover, the luxury consumption displays wealth and social status. This exploratory study, based on the questionnaire survey among clients of one of the Czech luxury tour operators, analyses the Czech luxury tourism market segment and reveals the luxury-driven attitudes and consumption patterns. In conclusion, the findings are compared with the results of similar foreign studies. The results suggest that Czech luxury tourists are both similar in a lot of cases (age group, motivation, type of accommodation, preferred destinations etc.) and different in comparison to the traditional European markets, especially regarding the financial possibilities. Most of the Czech tourists are willing to pay considerably lower amounts of money for luxury holidays. The frequency of their luxury holidays is also significantly lower. In this respect, but also for example in special interest (ecofriendly goods and services), the Czechs fall behind the European luxury tourists.
\end{abstract}

Keywords: luxury consumption, motivation, luxury travel, tourism demand; Czech Republic

\section{INTRODUCTION}

The development of the social status and lifestyle of consumers relates to various forms of tourism reflecting the requirements of the demand. One such form that is becoming more and more popular in the last decades is luxury tourism. A specific category of potential consumers who are seeking something exceptional highlights the benefit of experiences and material aspects of tourism. An increase in the consumption of luxury goods and services is in case of the luxury segment of tourism related to the search of unique services provided at an adequate level and with a possibility to have extraordinary experiences, which consequently corresponds with a higher price evaluation.

The significance of the luxury sector is demonstrated by an increasing trend at the world market for luxury personal goods that rose three and a half times between 1995 and 2015, from 77 billion to 253 billion Euros (D’Arpizio, Levato, Zito, \& Montgolfier, 2015). This 
market accounts for approximately $25 \%$ out of the entire luxury sector and is one of the most significant parts together with the segment of luxury cars (39\%) and "luxury hospitality" (17\%). "Hospitality" can be defined as an industry that includes hotels, restaurants and other facilities offering accommodation and food catering, as well as clubs, resorts, attractions and the like that create the base for (luxury) tourism and are an inspiration towards the demand for such industry (Barrows, Powers, \& Reynolds, 2012). The permeation of tourism and a luxury sector thus offers a significant potential and an interesting perspective for the future.

Even though the foreign professional literature has been dealing with luxury tourism largely for two decades (Bernstein, 1999; Silverstein \& Fiske, 2003; Kapferer, 2008; Page, 2009; Park, Reisinger, \& Noh, 2010; Hwang \& Han, 2014; Correia, Kozak, \& Kim, 2017; Han \& Hyun, 2018 and others), the research activities focused on luxury tourism in the Czech environment are rather sporadic. The presented study is thus a response to such situation, analysing the specific segment of the Czech luxury tourism. The objective of our contribution is to create a profile of Czech participants of such type of tourism, that is an affluent clientele, and explain their motivation to buy luxury services and products of tourism. The characteristic of the Czech participants of luxury tourism is researched on a sample of clients of a luxury travel agency by means of the questionnaire survey. We determined the factors that influence the way people decide when choosing their holiday and basic attributes of the stay/package holiday.

\section{THEORETICAL BACKGROUND}

The term "luxury" has been used so often recently that it may seem its original meaning is disappearing. One of the reasons might be the consistent global rise in the modern luxury market and globalization, a second reason might be the relativity and subjectivity of the term itself. The products and services that extend beyond the boundary of an elementary need, and with their price, quality, aesthetics and rarity exceed the general character may be considered luxurious (Bernstein, 1999). Such goods contribute to a personal satisfaction or strengthen the social status of the buyer. When deciding to buy luxury goods, the desire of the consumers to be part of the luxury market plays an important role (Heine \& Phan, 2011). Yet, a high price level of such products and services influence the number of consumers who can afford to buy them (Silverstein \& Fiske, 2003). The majority of ordinary consumers thus never or very rarely reach such products or services. For this reason, most people perceive the luxurious goods as "psychologically further away" than the necessary goods (Hansen \& Wänke, 2011).

Regardless of all definitions of luxury, it is necessary to consider that the term is subjective and that luxury is derived from the perception of the consumer. For this reason, 
Kapferer and Laurent (2015) support the idea to research and analyse the perception of consumers to detect the consumers' definition of luxury that could be exploited by managers and marketing experts dealing with a luxury market. Even though the status of several products might be considered luxurious from the perspective of the society, it is highly probable that not all individuals will agree whether the goods or the service is a luxury or a necessity, and therefore it is necessary to take this paradox into consideration. Within the luxury market, there is a vast range of potential levels (Heine \& Phan, 2011). Fig. 1. depicts the levels of luxury in the so-called Kapferer's pyramid (Kapferer, 2008).

Figure 1 Kapferer's pyramid of the level of luxury

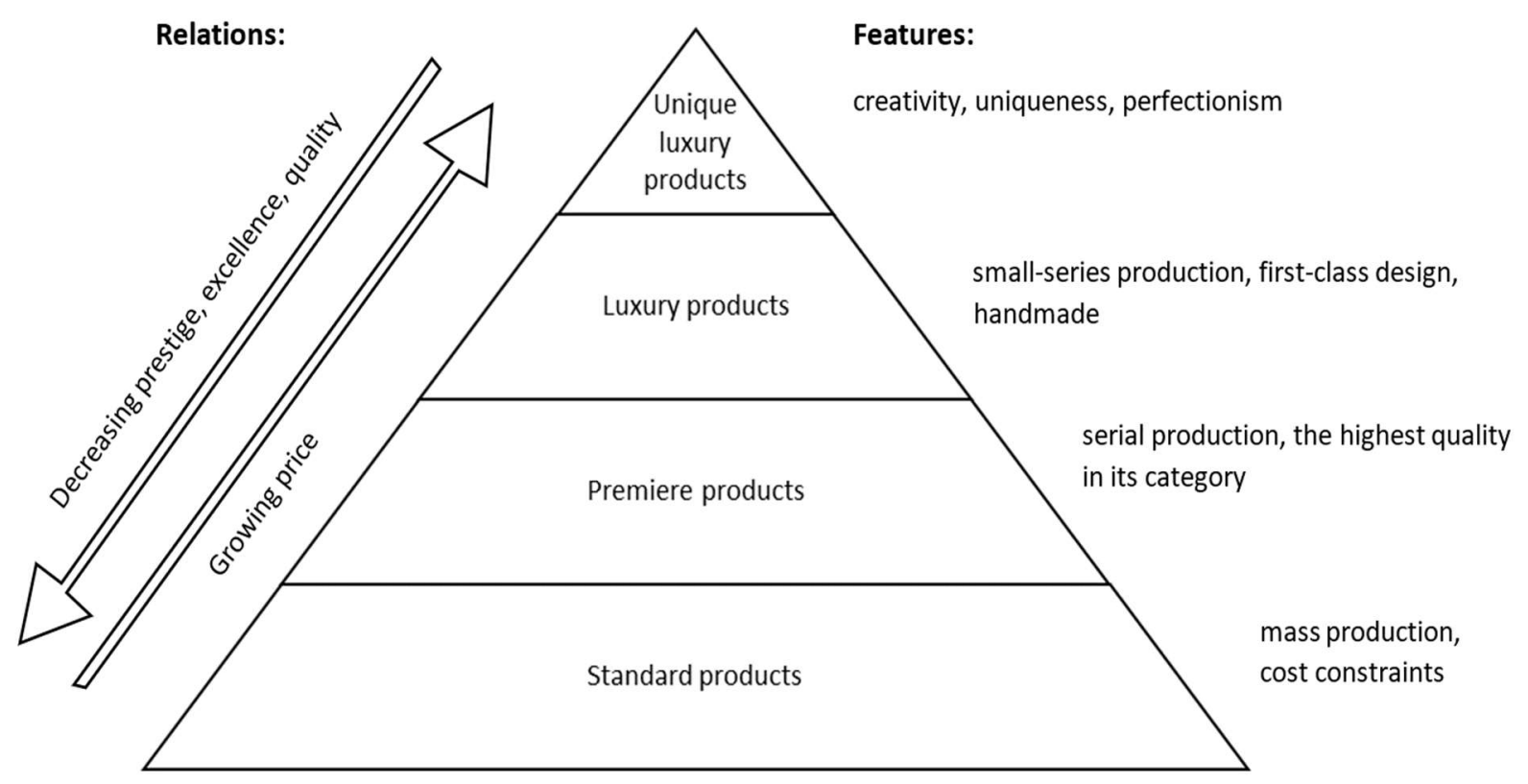

Source: Kapferer (2008, p. 98)

Just as the idea of luxury, the concept of tourism as well can be linked to the beginning of the human existence. Due to this fact, we can focus on luxury tourism within the general definition of the luxury sector in its strict sense. According to the data of UNWTO of 2011, the participants of the luxury tourism accounted for 3\% of all tourists worldwide and represented up to $20 \%$ of expenses on tourism (Chen \& Peng, 2014). The essential prerequisite of the growing importance of luxury tourism is the increase in the comfort and the welfare of society and greater availability of leisure time.

According to Page (2009), the luxury tourism is defined as a consumption of high-priced and high-quality experiences following the idea that the characteristics of luxury experiences evolve during the course of time. So for example staying in luxury resorts and hotels, tailormade package holidays or travelling by private planes belong to such experiences. The emphasis is put on comfort, relaxation and first-rate quality, while at the same time a high 
standard and unique and authentic services are expected (World Tourism Forum, 2014). In the luxury market, the main idea is to transform dreams into reality through tailor-made experiences. Such experiences are represented by stays in luxury hotels and resorts, luxury cruises, travel and luxury shopping, unique tailor-made holidays with authentic experiences or extreme experiences in unexplored places (Petrick \& Durko, 2015).

With regard to the above-mentioned findings, we may state that the luxury tourism is closely related to the so-called adventure tourism, as their common goal is to provide consumers with experiences (Pine \& Gilmore, 1999). The specifics of the luxury tourism lie in its cross-sectional nature interfering in other forms of tourism. In this way, we can detect luxury elements in for example spa tourism, cultural-cognitive tourism or congress tourism. The important common ground is the motivation of individuals by way of satisfying the need for holiday, regeneration, excursions or leisure time activities (Page 2009; Bacsi, 2017). Hallot (2013) points out that a luxury visitor has generally the same needs and desires as a common visitor. They undergo the same structure of experiences as it is with common tourism, which is demonstrated in Fig. 2.

Figure 2 The structure of experiences in tourism

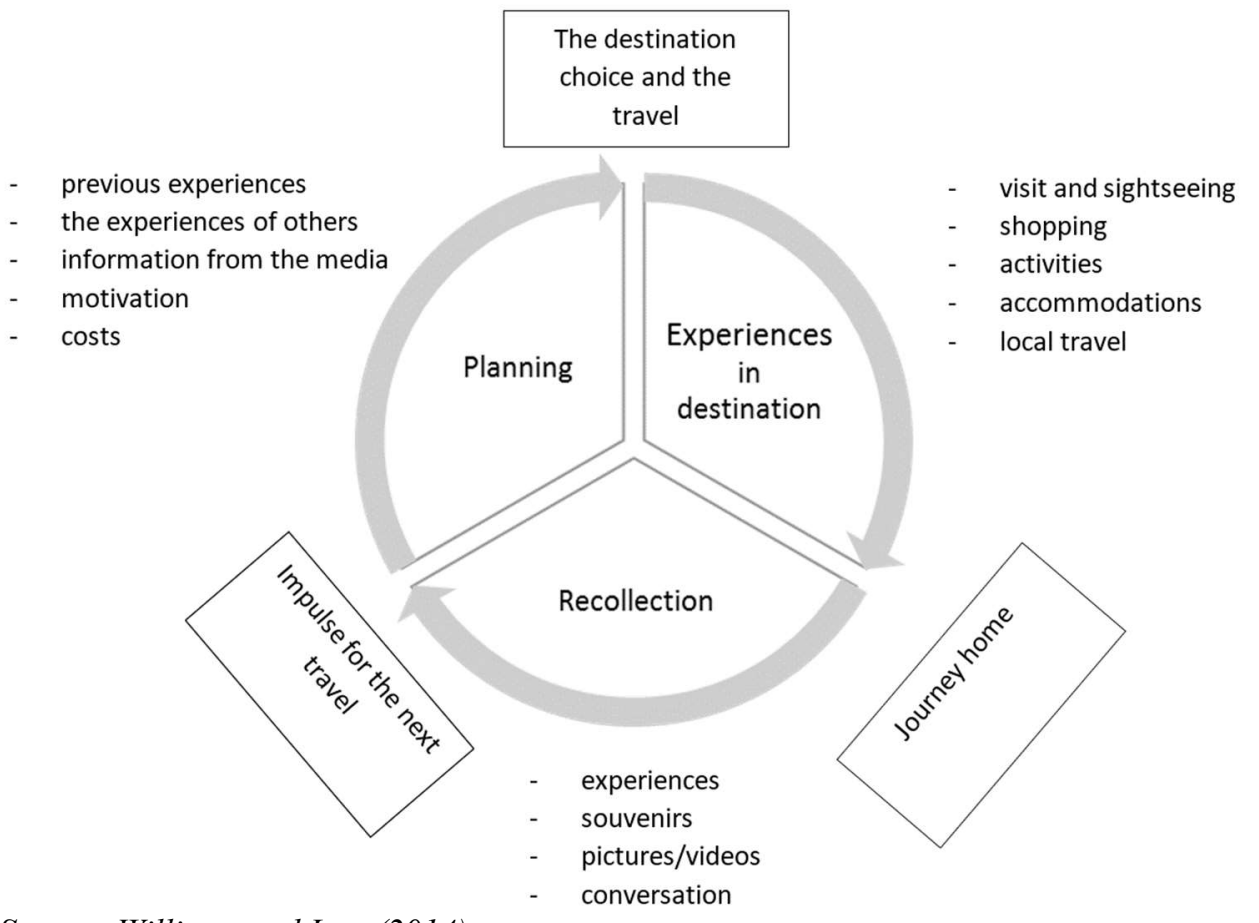

Source: Williams and Lew (2014)

Apart from common general needs such as relaxing, visits and sightseeing, social interaction and economic and sports reasons, the motivation of the participants in case of the luxury tourism is related to luxury places of stay, travelling to far-away exotic destinations, and searching for exciting experiences distinct from ordinary life (Pásková \& Zelenka, 2012). 
We can perceive experiences as a complex including a combination of factors that shape the feelings and attitudes of the participants of tourism towards the given moment. The experiences, therefore, affect individuals differently as their perception is based on various personal evaluations, be it an emotional or physical aspect. (Page, 2009; Ot'ahel', Ira, Hlavatá, \& Pazúr, 2018). The specifics of experiences in luxury tourism depend on the level of the demands of the travellers who usually wish to get authentic, exclusive and personalized experiences with a benefit paying huge sums of money. Such experiences might include e.g. individual excursions and trips, dinners at unique places (be it in renowned restaurants or in a secluded place in the countryside), or a chance to experience traditional rituals with local inhabitants in a given destination, etc. (Mahika, 2011).

As it was mentioned above, numerous studies in the last years were focused on examining the motivations (e.g. Uysal \& Jurowski, 1994; Baloglu \& Uysal, 1996; Yoon \& Uysal, 2005; Novanská, Benová, \& Geghamyan, 2018) that activate the needs for experiences and subsequently satisfy the needs by participation in tourism (Lee, Chua, \& Han, 2017). Based on the analysis of the motivations in tourism, types of tourism were created (Mahika, 2011). A study of demographic and socio-economic characteristics of consumers and their psychological stimuli thus became useful not only for managers but also for businessmen who wished to comprehend the behaviour of consumers and develop successful marketing strategies (Park \& Yoon, 2009; Kraftchick, Byrd, Canziani, \& Gladwell, 2014; Bobková \& Holešinská, 2017; Han \& Hyun, 2018). The providers of tourism services had to be able to predict the changes in motivations that predetermine the tourists to buy a package holiday or select a destination. Considering this, different motivations were hugely discussed, being caused on one hand by the real psychological motives (push factors), while on the other hand depending on specific characteristics of the destination, the so-called pull factors (Uysal \& Jurowski, 1994; Lesjak, Navrátil, Pícha, \& Gilliam, 2015).

It is obvious that the demand in the segment of tourism differs from a common segment e.g. by special interests and requirements. The specifics of the demand should be reflected on the grounds of thorough market segmentation that is the basis of the marketing strategy. The consulting company Horwath HTL (2011) assumes the typical participant of the luxury tourism to be somebody who uses air transport or a ship to get to the target destination, and the purpose of their trip is predominantly to discover, relax or change the pace of life. According to Peak and Skift (2014), nowadays people simply wish to travel better and at a 
higher emotional and personal level, they turn away from standardized, prearranged package holidays and their travel is more authentic, adventurous, active or locally focused. An affluent clientele starts to search for not only material standard, but also for a specific added value of non-material nature (Koch, 2011). Non-material nature is connected with personalized services including the preparation of the tour, the stay itself and the services after the return. The basic prerequisite is the ability to fulfil the personal requirements and provide services customised to fit the preferences of the clients. By its definition, the luxury tourism can be also perceived as a counterpart of the mass tourism. The basic characteristics of luxury and mass tourism are summarized in Tab. 1.

Table 1 The basic characteristics of luxury and mass tourism

\begin{tabular}{|l|l|}
\hline \multicolumn{1}{|c|}{ Luxury tourism } & \multicolumn{1}{c|}{ Mass tourism } \\
\hline Travelling of individuals or smaller groups & Travelling in larger groups \\
\hline $\begin{array}{l}\text { Representation of the older generation of } \\
\text { travellers }\end{array}$ & Rather younger generation of travellers \\
\hline Social class with a high income & Social class with lower income \\
\hline Tailored products & Catalogue-based and pre-arranged products \\
\hline Selective communication, selling dreams & Less selective communication, selling facts \\
\hline High quality connected with higher prices & Lower quality connected with lower prices \\
\hline Stressing the respect for the privacy of visitors & High concentration of visitors in the destination \\
\hline Stressing the prestige and unique experiences & Stressing the economic aspect and lower costs \\
\hline Hotels and resorts ****, luxury residences & $\begin{array}{l}\text { Hotels *** and collective accommodation } \\
\text { facilities }\end{array}$ \\
\hline Professional and trained staff & The lower level of professionalism of the staff \\
\hline High level of discreet behaviour & The lower level of privacy \\
\hline Use of high-quality means of transport & Use of cheap means of transport \\
\hline
\end{tabular}

Source: authors' processing based on Euromonitor International (2008); Pásková and Zelenka (2012)

The luxury tourism in the Czech Republic has a considerably shorter history than in the developed western countries. This is also linked with the perception of luxury by the Czech consumers, which is now getting closer to the perception of luxury by the affluent clients from the traditional countries such as USA, Japan, Germany, China, France or United Kingdom (Capgemini, 2019). The progress of the demand in the segment of luxury tourism corresponds to the growth trend set across the world. By Investopedia server (2018), a better validity regarding the potential luxury clientele presents the so-called concept of HNWI (High Net Worth Individuals) that includes individuals with liquid assets exceeding a specific limit, while the most frequent limit is 1 million USD. When applying the concept of HNWI, the number of US dollar millionaires in the Czech Republic amounts to approx. 
28,000 (Credit Suisse, 2017; Prague Daily Monitor, 2018). Compared to the global statistics with the entire value of 16.7 million of HNWI, it is a rather insignificant amount, yet the year-on-year growth in the Czech Republic, oscillating recently between 10-11\%, has reached the level of the global average, even exceeding it slightly, which also offers a range of opportunities for luxury tourism.

\section{DATA AND METHODS}

The basic methodological approach towards our research focused on the Czech luxury clientele is based on the theoretical knowledge using the professional literature and formerly published studies. Our own research is thus focused on the preferences and individual characteristics of the participants of luxury holidays organised by the Czech travel agency. The research questions were asked in such a way that when answering them, the Czech demand segment of the luxury tourism was characterized and the goal was thus accomplished, creating a profile of Czech participants of this type of tourism and explaining their consumption behaviour and motivation to purchase luxury services and products of tourism. The stipulated questions are as follows:

RQ1: What are the typical characteristics of the Czech luxury tourism participants and the main differences from European participants?

RQ2: What are the consumption patterns and factors that motivate the Czech demand segment to participate in the luxury tourism?

The research itself has a quantitative character (probability stratified sampling) and a method of questionnaire survey performed directly among the clients of one of a luxury travel agency at the Czech market was chosen. A range of more or less luxury travel agencies operates in the Czech market. To map the Czech market of luxury travel agencies is a quite difficult matter. The offer of some agencies pretends to be luxury. On the other hand, it includes sometimes elements characterized as less luxurious or common. The careful analysis of the offer of individual agencies shows that from a geographic perspective, some of the agencies focus only on specific regions or countries (e.g. Palmyra Tour and its specialization in Middle-East \& North Africa; agencies China Tours or Latintour). As the thematic focus regards, there are not only generally oriented travel agencies in the Czech Republic, but also a number of agencies specialized in luxury golf tours (e.g. S-Guide), 
expedition and sightseeing tours (e.g. Inspira, CK Viva Travel or Orbis Link), as well as incentive and congress travels (e.g. Connea Travel).

The selected joint-stock company called Deluxea was already established in 1995 and has been recently very successful at the Czech market. It belongs to the major Czech travel agencies operating in the luxury sector in the Czech Republic and offering general worldwide journeys. It is exclusively specialized in tailor-made luxury tours and exotic destinations. It is also considered to be one of the largest Czech luxury travel agencies by revenue.

The questionnaire was based on the relevant theoretical-methodical grounds using professional literature and real experiences of the employers of the travel agency. Its content was adjusted to the segment of respondents who are assumed to be affluent and solvent. The questions were aimed to ascertain the general opinion of the clients on the luxury tourism and their concepts of the luxury holiday. One sector of questions examined the motivations of the travellers. The other sectors covered questions concerning financial costs involved with the luxury holidays, participants' preferences and methods of the management of the holidays.

For the purpose of our own survey, we have chosen a digital survey, which was underway from November 2016 until April 2017. The questionnaires were being sent to the clients of the travel agency that provided us with its database of 2,671 e-mail addresses. 425 fully completed questionnaires were received. The final number of the returned questionnaires represents approximately $16 \%$ of the entire number of the distributed questionnaires, which may be considered as a decent return. From the spatial point of view (Tab. 2), all regions of the Czech Republic were represented, yet there was a certain influence by the location of the Deluxea travel agency offices in the largest cities of the country, Prague and Brno. Almost one-third of the clients of the luxury travel agency who participated in the questionnaire survey indicated the capital city of Prague as their place of residence, more than $10 \%$ of the respondents were represented by the Central Bohemian Region (hinterland of Prague) and the South Moravian Region (Brno). We believe that this distribution and the number of respondents is sufficiently representative concerning the national level and the narrow segment of the survey. 
Table 2 Spatial distribution of the Czech respondents

\begin{tabular}{l|r|l|r} 
Name of the region & share of the segment & Name of the region & share of the segment \\
\hline Capital city of Prague & $32.2 \%$ & Olomouc & $3.5 \%$ \\
\hline Central Bohemian & $14.1 \%$ & Zlin & $3.1 \%$ \\
\hline South Moravian & $12.9 \%$ & Hradec Kralove & $2.8 \%$ \\
\hline Moravian-Silesian & $5.4 \%$ & Liberec & $2.4 \%$ \\
\hline South Bohemian & $4.7 \%$ & Pardubice & $2.4 \%$ \\
\hline Usti nad Labem & $4.0 \%$ & Vysocina & $1.4 \%$ \\
\hline Plzen & $3.8 \%$ & Karlovy Vary & $0.9 \%$
\end{tabular}

Source: authors' research

To evaluate the results, mathematical-statistical and analytical methods were applied using mostly one-dimensional and two-dimensional statistical analysis. The data were processed with the help of MS Excel software and SPSS statistical programme.

\section{RESULTS}

In the current competitive environment, there are growing demands for personalisation of the product for the target market. It is highly important to focus on the exact aim of the product and effective use of the marketing tools in order to segment the target customers. Therefore, the participant of the luxury tourism is classified according to socio-demographic characteristics of the researched segment, their concepts of the luxury holiday and motives for such travelling are determined. To create an overall concept of the Czech affluent clientele, the information is supplemented with time and financial aspects of the luxury tourism.

As far as the socio-demographic characteristics are concerned (Tab. 3), the category between 35 to 59 years of age is the most dominant one among the affluent clients (both couples and individuals) and it represents almost two-thirds individuals out of the entire number. By contrast, only an insignificant quantity of people under 25 years was found in the researched sample. The most frequent respondents were men between 35 and 49 years ( $21 \%$ of all respondents) and between 50 and 59 years (18\%). Women were characterized by a lower age, while the age category was the same as with men, 35 to 49 years (15\%), yet the second most numerous group were women between 26 and 34 years (12\%). More than $60 \%$ of the participants in the luxury holidays who took part in the survey were tertiaryeducated people. The results show that the participants of the luxury holidays are predominantly educated persons with tertiary or at least secondary education. As far as the 
economic status is concerned, people with a regular income, or rather anybody with a regular employment, was among the most frequent respondents (more than 86\%).

Table 3 Socio-demographic characteristics of the respondents

Characteristic

| Absolute frequency $\mid$ Relative frequency

\begin{tabular}{l|c|c}
\hline Sex & 236 & $55.5 \%$ \\
\hline Men & 186 & $43.8 \%$ \\
\hline Women & 3 & $0.7 \%$ \\
\hline Not answered & \multicolumn{2}{|c}{} \\
\hline Age category & 2 & $0.5 \%$ \\
\hline Up to 25 years & 74 & $17.4 \%$ \\
\hline $26-34$ years & 152 & $35.8 \%$ \\
\hline $35-49$ years & 126 & $29.6 \%$ \\
\hline $50-59$ years & 71 & $16.7 \%$ \\
\hline 60 and more & 2 & $0.5 \%$ \\
\hline Education & 17 & $4.0 \%$ \\
\hline Primary & 142 & $33.4 \%$ \\
\hline Secondary without a school-leaving exam & 257 & $60.5 \%$ \\
\hline Secondary with a school-leaving exam & 7 & $1.6 \%$ \\
\hline Tertiary & \multicolumn{2}{|c}{} \\
\hline Not answered & 366 & $86.1 \%$ \\
\hline Economic status & 4 & $0.9 \%$ \\
\hline Employed/employer/self-employed & 12 & $2.8 \%$ \\
\hline Unemployed & 37 & $8.7 \%$ \\
\hline Maternity leave & 2 & $0.5 \%$ \\
\hline Student & 4 & $0.9 \%$
\end{tabular}

Source: authors' research

According to more than two-thirds of answers, respondents associate the term "luxury holiday" with first-rate and personalized services. An appropriate finding corresponds with the nature of the luxury tourism, as well as the second most frequent answer, which was an association with a carefree stay. It is common across the world that luxury holidays are often tailor-made for particular tasks and choices of the clients, which was confirmed by almost one-half of the respondents. Other options are mentioned in Fig. 3. It is interesting to mention that as far as the age category is concerned, especially younger respondents associate the luxury holiday with a carefree stay, while people over 50 years of age would opt for the tailor-made holiday. 
Figure 3 Preferences on a luxury holiday

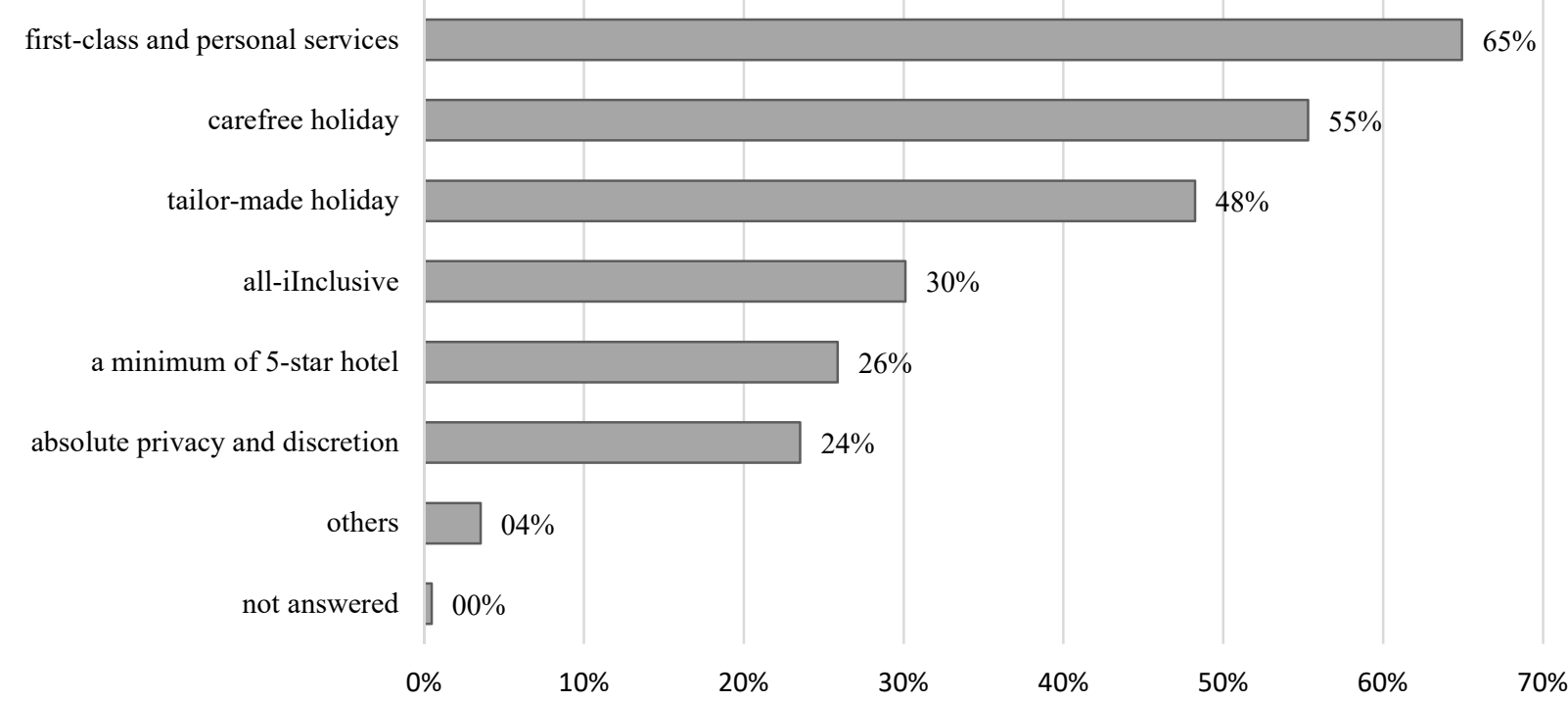

Source: authors' research

Generally, the majority of the affluent clients whose travelling is costly with luxury attributes have their holiday tailor-made. Overall, we can state that a higher level of organization is typical for these types of holidays. In view of the above-mentioned findings from the questionnaire survey concerning the carefree stay and first-rate services, it is not a surprise that the Czech affluent clientele (52\%) prefer all-inclusive (four or five-stars hotels) and tailor-made luxury holidays (Fig. 4). More than a half of the respondents are thus clients of travel agencies that guarantee ready-made holiday packages inclusive of the reservation, transport, trips, excursions and other activities. Two-fifths of the respondents are satisfied with partly organized holidays inclusive of e.g. hotel and flight tickets reservation. Other attributes of the stay are organised by the clients themselves. Only $8 \%$ of the respondents prefer to organize all tour by themselves.

Ready-made holiday packages are preferred by respondents including retired people, unemployed, women on maternity leave and students (64\%) and respondents over 50 years $(55 \%)$. In case of partly organized luxury holidays, the situation is the opposite, i.e. they are more preferred by employed people and people below 50 years. This is related to the fact that the more affluent the clients are, the more they tend to use tailor-made services. 
Figure 4 The level of organization of the luxury holiday

completely tailored to client's requirements

$$
\text { partly organized holiday }
$$

unorganized holiday with own booking and program

not answered

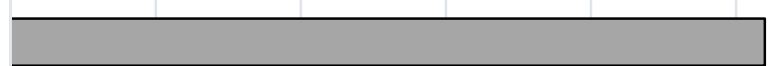

$52 \%$

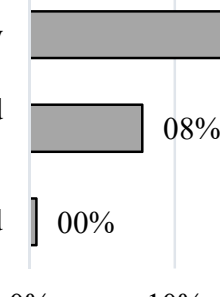
$8 \%$ $10 \%$
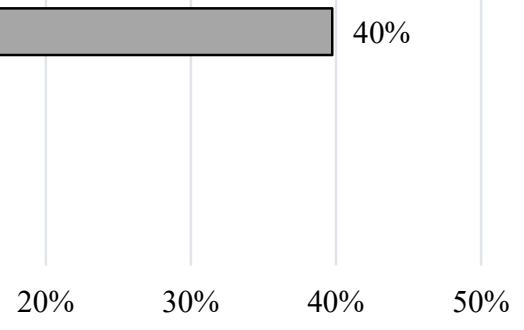
$60 \%$

Source: authors' research

The board basis is also important for clients when choosing the holiday. For the majority of the respondents, comfort and carefree holiday are important, so almost $60 \%$ of them opt for the all-inclusive type of holiday. These participants of the luxury holidays prefer to choose such type of holiday where they need not be concerned about choosing the board basis. Only a minimum of respondents prefer full-board or self-catering holiday.

Regarding the motivation of the participants of luxury holidays, the numerical scale ranging from 1 to 5 was used to show which character of destination is most attractive for the respondents (value of 1 represents "the most important" and 5 "the least important"). According to the results, the respondents are most attracted by the beach and the sea. Almost $80 \%$ of the respondents assign it to the value of "the most important", which is much more than in case of other possible answers. The second most important factor is the nature and attractiveness, which is ranked among the most important character by more than a half of the respondents. Culture and history, too, play a significant role. By contrast, mountains and skiing, cruises and urban tourism or cities are less interesting for the respondents. Men tend to prefer culture and history, nature, mountains and skiing and luxury cruises, while women prefer the beach by the sea and urban tourism. Nevertheless, the overall preferences in Tab. 4 are similar to those mentioned by men or women. The median is also available, expressing the middle value of answers for individual sub-questions and dividing the set of answers into two equal halves. 
Table 4 The character of the destination

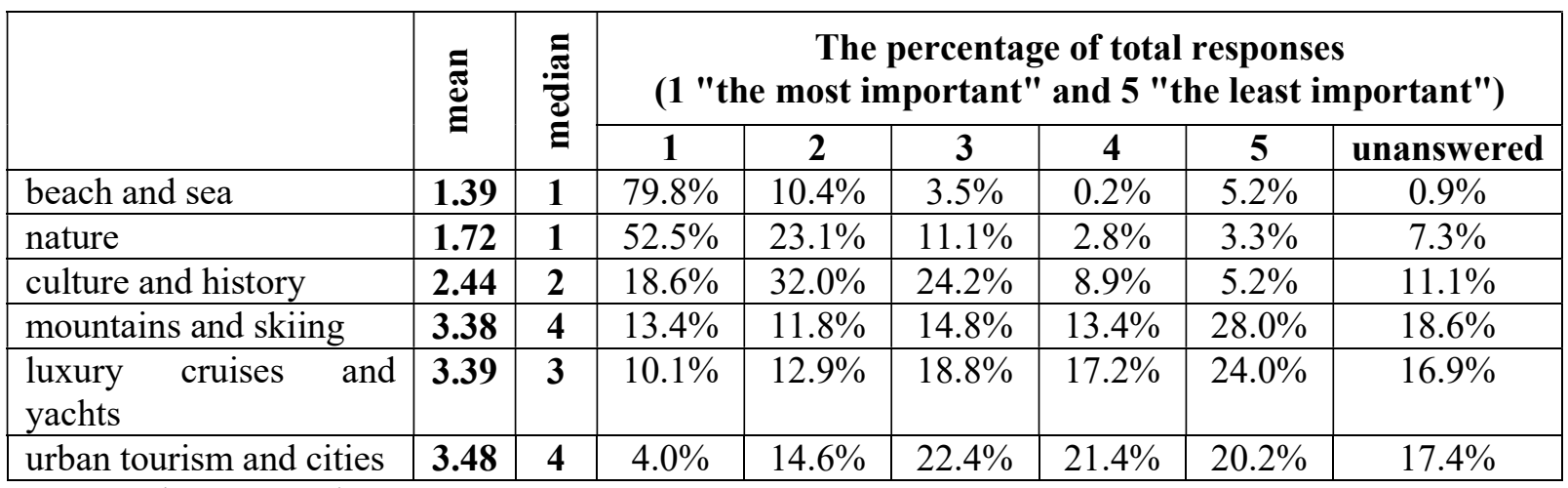

Source: authors' research

For more than $90 \%$ of the participants of luxury holidays, the main reason to travel is relaxation, which includes exploring the nature and relaxation itself. For more than twothirds of the respondents, the main reason is to explore the destination. This is also connected to the destination's history and culture. For almost $35 \%$ of the respondents, sports activities are an essential part of the holiday, for a little fewer people it is the health improvement, entertainment or celebration of an important anniversary. Only a few people travel for business, as it was mentioned only by several individuals.

An expression of their motivation is depicted in the form of a "word cloud" (Fig. 5). This is a visual representation of the most frequently used answers of the respondents in the questionnaires. The frequency is described by the font size. The word "relaxation" is repeated in $94 \%$ of the cases in total, followed by the words "attractiveness", "history", and "culture" (68\%).

Figure 5 Motivations of luxury clients for travelling

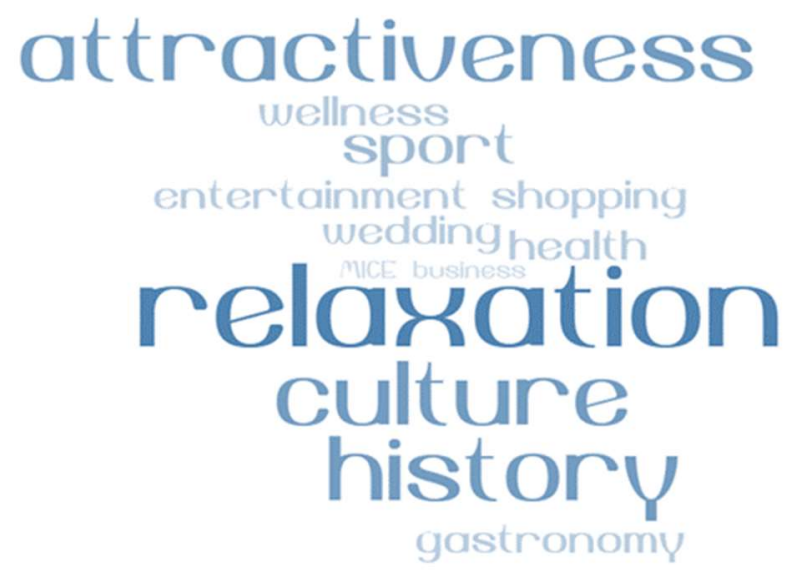

Source: authors' research 
The aim of the questions targeted at the time aspects of the luxury travelling was to ascertain which season is most preferred by the respondents for travelling. The Czech participants of luxury holidays prefer to travel in the off-summer months (Fig. 6), which represent the main season in the Czech Republic. During this season, one can enjoy the sunshine in the home country without the need to travel abroad. Yet, more than a quarter of the respondents do not have any preferences at all. Approximately $26 \%$ of the respondents' decisions are based on the season in the destination.

Figure 6 Preferred season for travelling

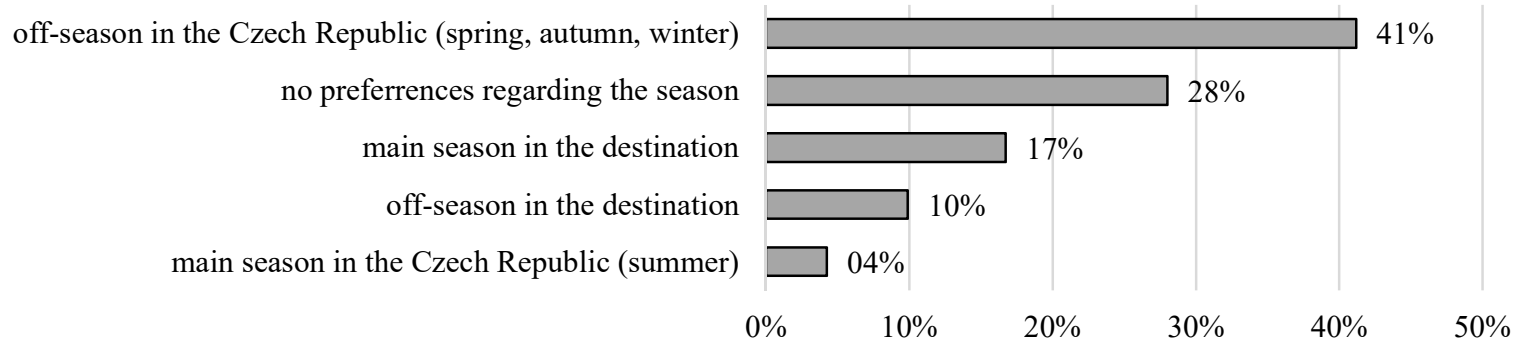

Source: authors' research

The preference to travel off-season is also related to the fact that the participants of the luxury holiday prefer exotic places. According to the respondents, luxury holidays are mostly related to the places in the Indian Ocean, along with the Caribbean Sea and the Pacific Ocean (Fig. 7). We can conclude that luxury touristic places are typical for their tropical or exotic features and a great distance from the Czech Republic. 
Figure 7 Luxury destinations according to the Czech respondents

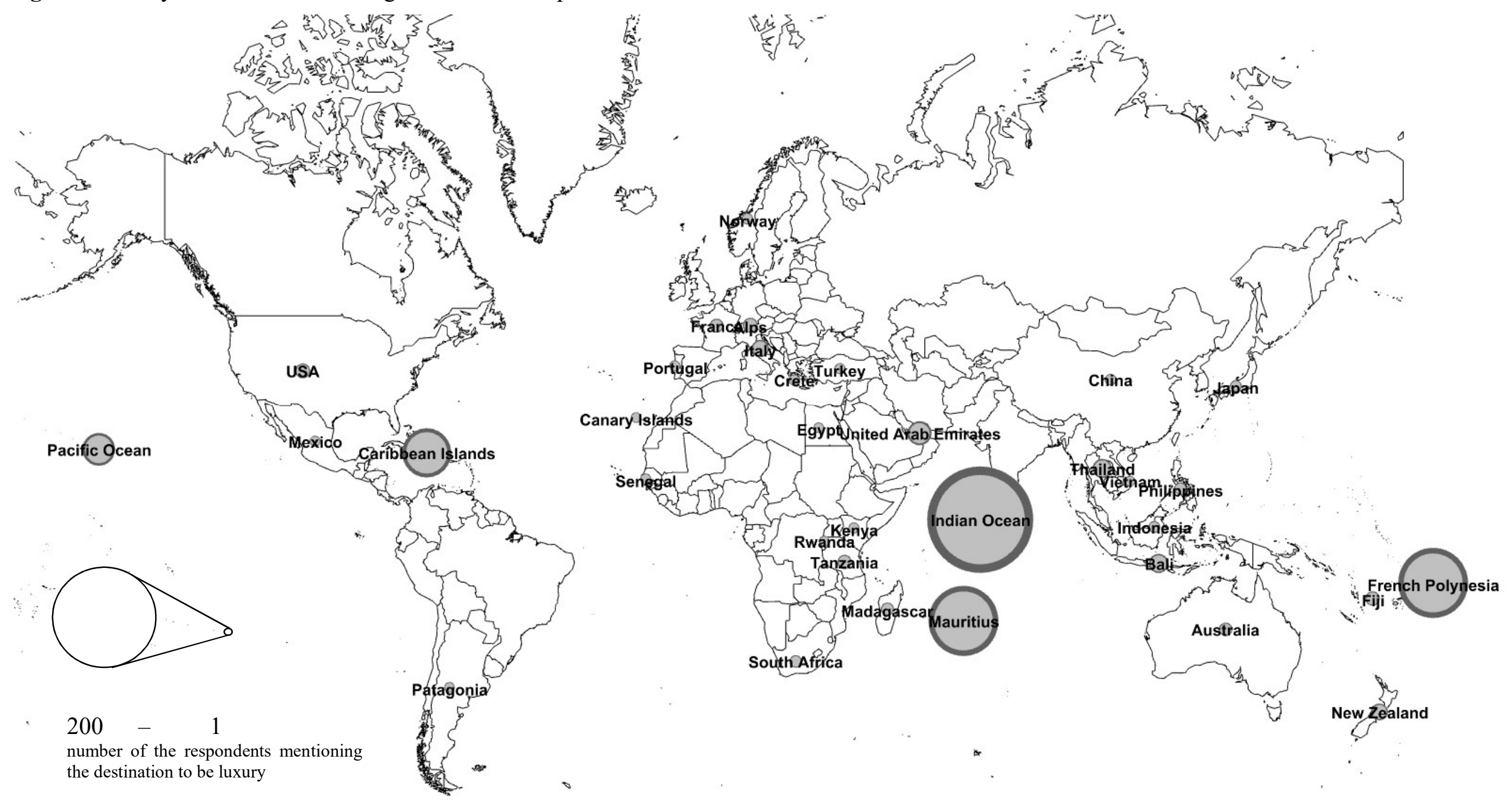

Source: authors' research 
According to the next question dealing with the frequency of travels, the clients involved in the questionnaire survey take one luxury holiday per year in more than two-thirds of the cases. Among the main reasons may be included a lack of financial resources and a lack of time. The second frequent group involves participants who take a luxury holiday two or three times a year. Fewer than $3 \%$ of the respondents take more than four luxury holiday per year. As far as the time concept is involved, we must not forget the average length of the holiday spent by the participants of the luxury holidays (Fig. 8). In this case, almost three-quarters of the respondents chose the option of 8-15 nights. It corresponds to the fact that it is worthwhile to spend more nights when travelling to faraway destinations. At the same time, more than one-fifth of the respondents prefer to stay between 5 and 8 nights.

Figure 8 Average time spent on luxury holiday

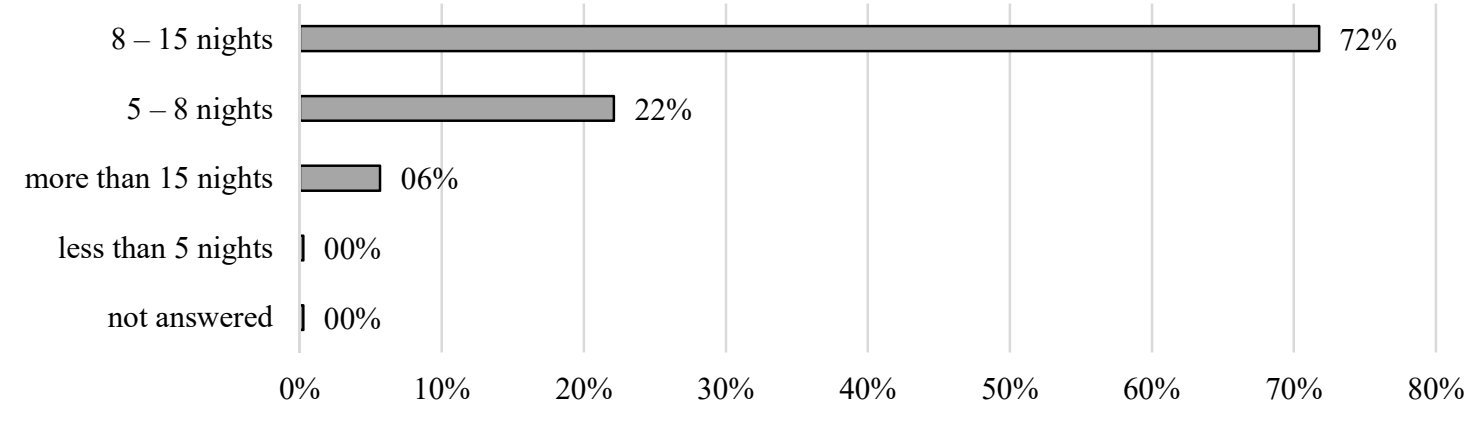

Source: authors' research

Two-thirds of younger people usually spend 8-15 nights on their holiday, and $27 \%$ of these respondents then 5-8 nights. The same order is observed with luxury tourists over 50 years of age, out of which $77 \%$ prefer to spend $8-15$ nights on their holiday and merely $16 \%$ of them prefer luxury holidays with 5-8 nights. Younger luxury clients thus spend a fewer number of nights on their holiday, most likely due to their lack of time and workload.

Financial resources (Fig. 9) play an important part in the context of the luxury holidays, considerably exceeding the price level of regular holiday packages. Almost one-half of the respondents stated that they are willing to pay no more than 2,800 Euros for their luxury holiday. The range between 2,800 and 4,000 Euros is the second most frequent amount of money invested in luxury holiday mentioned by more than one-third of the respondents. The smallest number of people is willing to spend more than 4,000 Euros. There are particular differences when analysing the expenses of men and women, when $56 \%$ of men are ready to spend more than 2,800 Euros on the luxury holiday of 7 nights, while only $46 \%$ of women are 
willing to pay the same amount. This conclusion may also encourage the gender topics, when men usually earn more money and are afterwards willing to pay more for luxury holidays. Another issue concerning the detailed analysis is to what extent the education influences the amount of the expenses on holiday. It was found out that the share of the respondents who spend less than 2,800 Euros is falling with growing education.

Figure 9 Costs per person on a 7-night luxury holiday

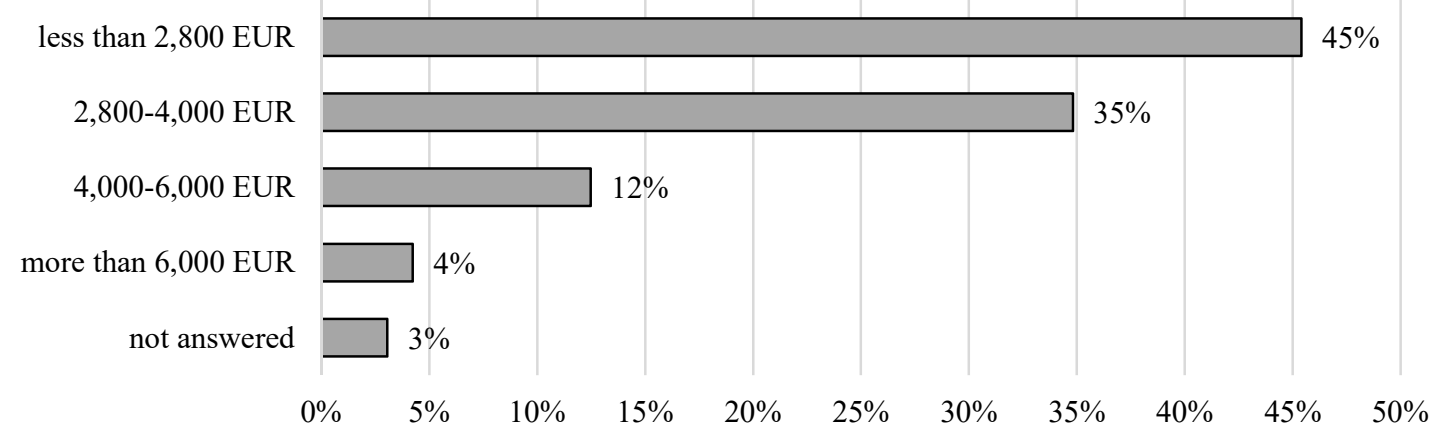

Source: authors' research

\section{DISCUSSION AND CONCLUSION}

In the discussion, we would like to explain how the results relate to the relevant literature and suggest any implications they might have for the future marketing strategies. The growing number of affluent clients and their increasing wealth cause that the luxury segment is developing and expanding all the time, which provokes a response from the designers of the marketing strategy. The issue of the luxury travelling is, therefore, becoming a part of the research activities. Expert studies (mostly case studies), narrowly focused on affluent clientele and the luxury segment of the tourism, are often related to the research of the quality of the services offered (hotels, restaurants, etc.) as well as the environmental impacts of building and managing the luxury resorts in, for a European person, exotic destinations such as island states or city-states in the Caribbean, the Indian Ocean or Southeast Asia (e.g., Carey, 1989; Ka Wai Lai \& Hitschcock, 2016; Chen \& Peng; 2018; Cowburn, Moritz, Birrell, Grimsditch, \& Abdulla, 2018; Novotná \& Kunc, 2019). These are predominantly developing economies that depend to a great extent on tourism revenues.

The mentioned activities are at their very beginnings in the Czech Republic, as it has been only recently when the aspects of luxury started to be perceived by the Czech consumers in a similar way as by the affluent clients from traditional European countries such as France, Great 
Britain or Germany. Our contribution reflects this fact and it defines the demand segment of luxury tourism in the Czech Republic, which might be considered unique within Central Europe. Such knowledge of sociodemographic characteristics of the Czech affluent clientele and their consumer behaviour may be a guideline to choose a suitable marketing strategy for this market segment. We may use e.g. the amount of the travelling expenses as a variable as a useful alternative instead of the general segmentation according to travelling activities.

Due to the limited possibilities of comparisons (see above), one of the most available comprehensive research of the demand for luxury holidays called Luxury Travel Trends from Pangea Network $(2014,2017)$ - which is an international organization of independent agencies specializing in consultancy, marketing and communication services in tourism - was chosen in order to compare the Czech affluent clientele and their profilation with other European participants of luxury tourism. The agency implemented its research, besides other things, in 6 European source markets, which are France, Germany, Italy, Spain, Netherlands and Great Britain. These markets may be regarded as relevant to the profilation of a participant of luxury tourism, also thanks to the fact that they belong to the main source markets concerning the demand in the luxury tourism.

As it can be seen from the Tab. 5, a typical Czech participant of luxury tourism is considerably different from the European one (representing all European countries), while at the same time similar consumers' behaviour, motivation and activities can be noticed. Czech participants in the luxury holidays are different as far as the financial possibilities are concerned, as they are usually willing to pay less amount of money for their luxury holiday. The frequency of travelling is lower, as well as the type of the preferred air transport. In these aspects, the Czech tourists are definitely falling behind the European luxury tourists. Yet, the situation is similar when regarding the organization of the holiday (the so-called "tailor-made" packages prevail), as well as the board basis (All inclusive), the choice of the holiday and the motives for travelling such as first-rate and all-inclusive services, comfort and relaxation. European luxury tourists are more focused on unique experiences and pay attention to ecofriendly goods and services. According to an expert on luxury tourism from Deluxea travel agency who has been recently interviewed by way of additional controlled interviews, it is obvious that requirements and possibilities of the Czech affluent clientele change rather quickly and in near future they will equal the clients from the developed European countries. The expert also mentions that this future progress means a bigger emphasis of the Czech clients on a certain added value of non-material character, which was now expected rather by the clientele from the developed countries. 
Table 5 A comparison of the consumption patterns and motivation

\begin{tabular}{|c|c|}
\hline $\begin{array}{l}\text { Czech affluent clientele } \\
\text { (Authors' research) }\end{array}$ & \begin{tabular}{|c|} 
European affluent clientele \\
(Pangea Network, 2014, 2017)
\end{tabular} \\
\hline \multicolumn{2}{|c|}{ The most frequent age group (years) } \\
\hline $35-59$ (both couples and individuals) & 36-55 (couples, generation $\mathrm{X}$ is the main target) \\
\hline \multicolumn{2}{|c|}{ Influence on tour choice } \\
\hline Information from friends and tour specialist & $\begin{array}{l}\text { Information from friends, relatives, and online } \\
\text { reviews }\end{array}$ \\
\hline \multicolumn{2}{|c|}{ The choice of the holiday according to (expectation of) } \\
\hline First-rate and personal services $(65 \%)$ & Added value $(65 \%)$ \\
\hline \multicolumn{2}{|c|}{ Motivations to travel } \\
\hline $\begin{array}{l}\text { Relaxation, nature and attractiveness, culture, } \\
\text { history, mountains and skiing }\end{array}$ & $\begin{array}{l}\text { Comfort and rest, completeness of services, new } \\
\text { destinations, authenticity, unique experiences, } \\
\text { culinary experiences, and culture tours }\end{array}$ \\
\hline \multicolumn{2}{|c|}{ The level of organization of the holiday } \\
\hline "Tailor-made" (52\%), Partly organized (40\%) & "Tailor-made" (69\%) \\
\hline \multicolumn{2}{|c|}{ The preferred season for holiday } \\
\hline $\begin{array}{l}\text { Off-season in the Czech Republic (spring, } \\
\text { autumn, winter) }(41 \%)\end{array}$ & Winter, summer $(25 \%)$ \\
\hline \multicolumn{2}{|c|}{ The preferred accommodation type } \\
\hline Luxury hotels (four or five-stars) & $\begin{array}{l}\text { Exclusive boutique hotels or the best } \\
\text { international hotel brands }\end{array}$ \\
\hline \multicolumn{2}{|c|}{ The most frequent length of the holiday } \\
\hline $8-15$ days, 1 holiday $(72 \%)$ & 10 days, 4 and more holidays (47\%) \\
\hline \multicolumn{2}{|c|}{ The most frequent costs per person } \\
\hline Up to 2800 thousand Euros $(45 \%)$ & $5-10$ thousand Euros $(54 \%)$ \\
\hline \multicolumn{2}{|c|}{ The character of the destination } \\
\hline $\begin{array}{l}\text { Beaches and sea }(78 \% \text {; the Indian Ocean, the } \\
\text { Caribbean and the Pacific Ocean), Nature and } \\
\text { attractiveness }(52 \%)\end{array}$ & $\begin{array}{l}\text { the Caribbean and Brazil, the Indian Ocean } \\
\text { Islands, East and South-east Asia, United Arab } \\
\text { Emirates, South Africa, Australia }\end{array}$ \\
\hline \multicolumn{2}{|c|}{ Special interest } \\
\hline $\begin{array}{l}\text { No special interest, just balanced price / quality } \\
\text { ratio }\end{array}$ & pay attention to eco-friendly goods and services \\
\hline \multicolumn{2}{|c|}{ Board-basis } \\
\hline All Inclusive (60\%) & \begin{tabular}{|l} 
All Inclusive (69\%) \\
\end{tabular} \\
\hline
\end{tabular}

Source: authors' research

Based on the above-mentioned findings, we may find answers to the research questions stipulated in the methodical part of the presented contribution. In order to answer RQ1, it was necessary to define a Czech participant in the luxury tourism. Such a person is middle-aged with a tertiary education and employed. Typical features of the luxury holiday of such person include e.g. All inclusive, first-rate and personal services, and the possibility to relax in an exotic country during a period when it is the off-season in the Czech Republic (in the offsummer months).

RQ2 focused on the consumption patterns and motivation of the Czech demand segment to participate in the luxury tourism may be answered by using the above-defined push and pull 
factors. The psychological incentives may be considered a primary motive, leading to the satisfaction of the needs for relaxation that implies push factors. While specific characteristics of the destination are the secondary motive for luxury tourism (pull factors), more than twothirds of the respondents' state that getting to know the attractiveness of the destination is the motivation for taking their holidays.

From the findings found not only in the research, it is possible to confirm the indisputable importance and growth tendencies of luxury tourism, even though it is a form of travel adapted only for a limited range of participants and thus a combined offer (e.g. Radiant Insights, 2018; Adroit, 2019). The situation in more developed countries is still ahead of the state of luxury tourism in the Czech Republic. However, the signs of catching up and leveling the world standards in terms of domestic supply and travel habits of domestic demand are positive. These facts are also confirmed by expert studies of Pangea Network $(2014,2017)$ expecting that highspending travellers will be very demanding, informed and increasingly sensitive to eco-friendly travel solutions. Generally, luxury travel is expected to increase by $6-10 \%$ over the next $2-3$ years.

\section{Acknowledgement}

This contribution was supported by an internal grant of the Faculty of Economics and Administration, Masaryk University, entitled "Destination Sustainability under the Pressure of Global Tourism Trends" (MUNI/A/1166/2018).

\section{REFERENCES}

Androit (2019). Global Luxury Travel Market by Age Group, by Application, by Region and Forecast 2018 to 2025. [online]. Available from: https://www.adroitmarketresearch.com/industry-reports/luxury-travel-market.

Baloglu, S., \& Uysal, M. (1996). Market segments of push and pull motivations: canonical correlation approach. International Journal of Contemporary Hospitality Management, 8(3), pp. 32-38.

Barrows, C. W., Powers, T. F., \& Reynolds, D. E. (2012). Introduction to Management in the Hospitality Industry. 10th Edition. Hoboken, New Jersey: Wiley, 720 p. ISBN 9780470399743.

Bacsi, Z. (2017). Tourism and diversity. Deturope, 9(2), 25-57.

Bernstein, L. (1999). Luxury and the Hotel Brand: Art, Science, or Fiction? Cornell Hotel and Restaurant Administration Quarterly, 40(1), pp. 47-53. ISSN 0010-8804.

Bobková, M., \& Holešinská, A. (2017) Networking in a destination from the perspective of virtual relationships and their spatial dimension. Geographia Technica, 12 (2), 10-19. ISSN 2065-4421. DOI: 10.21163/GT 2017.122.02

Capgemini. (2019). World Wealth Report 2019. [online]. Available from: https://worldwealthreport.com/wp-content/uploads/sites/7/2019/07/World-WealthReport-2019.pdf

Carey, K. (1989). Tourism Development in LDCs: Hotel Capacity Expansion with Reference to Barbados. World Development, 17(1), pp. 59-67. 
Correia, A., Kozak, M., \& Kim, S. (2017). Investigation of Luxury Values in Shopping Tourism Using a Fuzzy-Set Approach. Journal of Travel Research, 0047287517741005.

Cowburn, B., Moritz, C., Birrell, C., Grimsditch, G., \& Abdulla, A. (2018). Can luxury and environmental sustainability co-exist? Assessing the environmental impact of resort tourism on coral reefs in the Maldives. Ocean and Coastal Management, 158, pp. 120127.

Credit Suisse. (2017). Global Wealth Report 2015. [online]. Available from: https://www.credit-suisse.com/about-us/en/reports-research/global-wealth-report.html.

D'Arpizio, C, Levato, F., Zito, D., \& Montgolfier, J. (2015). Luxury Goods Worldwide Market Study. Bain \& Company. [online]. Available from: http://www.bain.com/publications/articles/luxury-goods-worldwide-market-studywinter-2015.aspx.

Euromonitor International (2008). Global Travel \& Tourism A Fast-changing Landscape.

Hallot, A. (2013). The future potential for developing luxury tourism and hospitality in Lapland. Diploma Thesis. Helsinki: Haaga Helia University.

Han, H., \& Hyun, S. S. (2018). Role of motivations for luxury cruise traveling, satisfaction, and involvement in building traveler loyalty. International Journal of Hospitality Management, 70, pp. 75-84.

Hansen, J., \& Wänke, M. (2011). The Abstractness of Luxury. Journal of Economic Psychology, 32(5), pp. 789-796. ISSN 01674870.

Heine, K., \& Phan, M. (2011). Trading-up mass-market goods to luxury products. Australasian Marketing Journal, 19(2), pp. 108-114. ISSN 1441-3582.

Horwath HTL (2011). The future of luxury travel. ILTM Asia. [online]. Available from: http://www.citsmice.net/other-reports/10_The future_of_luxury travel_report.pdf.

Hwang, J., \& Han, H. (2014). Examining strategies for maximizing and utilizing brand prestige in the luxury cruise industry. Tourism Management, 40, pp. 244-259.

Chen, A., \& Peng, N. (2014). Examining Chinese Consumers' Luxury Hotel Staying Behavior. International Journal of Hospitality Management, 39, pp. 53-56. ISSN 0278-4319.

Chen, A., \& Peng, N. (2018). Examining consumers' intentions to dine at luxury restaurants while traveling. International Journal of Hospitality Management, 71, pp. 59-67.

Investopedia - HNWI, (2018). [online]. Available from: https://www.investopedia.com/terms/h/ hnwi.asp>.

Ka Wai Lai, I., \& Hitchcock, M. (2016). A comparison of service quality attributes for standalone and resort-based luxury hotels in Macau: 3-Dimensional importance-performance analysis. Tourism Management, 55, pp. 139-159.

Kapferer, J. N. (2008). The new strategic brand management: creating and sustaining brand equity long term. 4th ed., New ed. Philadelphia: Kogan Page, xv, 560 p. ISBN 0749450851.

Kapferer, J. N., \& Laurent, G. (2015). Where Do Consumers Think Luxury Begins? A Study of Perceived Minimum Price for 21 Luxury Goods in 7 Countries. Journal of Business Research, 69(1), pp. 332-340. ISSN 0148-2963.

Koch, K. D. (2011). Luxury Tourism - Does This Segment Still Work? In Conrady, Roland a Buck Martin (Eds.), Trends and issues in global tourism 2011. Heidelberg: Springer, 2011. ISBN 9783642177675.

Kraftchick, J. F., Byrd, E. T., Canziani, B., \& Gladwell, N. J. (2014). Understanding beer tourist motivation. Tourism Management Perspectives, 12, pp. 41-47.

Lee, S., Chua, B. L., \& Han, H. (2017). Role of service encounter and physical environment performances, novelty, satisfaction, and affective commitment in generating cruise passenger loyalty. Asia Pacific Journal of Tourism Research, 22(2), pp. 131-146. 
Lesjak, M., Navrátil, J., Pícha, K., \& Gilliam, V. L. W. B. (2015). The Predictors of the Willingness to Recommend a Visit for Diversified Tourism Attractions. Czech Journal of Tourism, 4(2), 77-90. DOI: 10.1515/cjot-2015-0005.

Mahika, E. C. (2011). Current trends in tourist motivation. Cactus Tourism Journal, 2(2), pp. $15-24$.

Novanská, V., Benová, A., \& Geghamyan, S. (2018). Options for recreation in the city of Bratislava based on the perception of local inhabitants. Geographia Cassoviensis, 8(1), pp. 110-128.

Novotná, M., \& Kunc, J. (2019). Luxury tourists and their preferences: Perspectives in the Czech Republic. Tourism : An International Interdisciplinary Journal, 67(1), pp. 90-95.

Ot'ahel', J., Ira, V., Hlavatá, Z., \& Pazúr, R. (2018). Visibility and perception analysis of city monuments: The case of Bratislava city centre (Slovakia). Moravian Geographical Reports. 26(1), pp. 55-68.

Page, S. J. (2009). Tourism Management: Managing for Change. 3rd edition. Amsterdam: Elsevier/Butterworth-Heinemann, 578 p. ISBN 9781856176026.

Pangea Network. (2014). Luxury travel trends. 4th edition. [online]. Available from: $<$ http://www.blueroom.es/wp-content/uploads/2012/07/Luxury-Travel-Trends-Report4th-Edition.pdf $>$.

Pangea Network. (2017). Luxury travel trends. 5th edition. [online]. Available from: $<$ https://www.italiaconvention.it/en/news-en/luxury-travel-international-trends/>

Park, D. B., \& Yoon, Y. S. (2009). Segmentation by motivation in rural tourism: A Korean case study. Tourism Management, 30(1), pp. 99-108.

Park, K. S., Reisinger, Y., \& Noh, E. H. (2010). Luxury shopping in tourism. International Journal of Tourism Research, 12(2), pp. 164-178.

Pásková, M., \& Zelenka, J. (2012). Výkladový slovník cestovniho ruchu. Kompletně přepracované a doplněné 2. vydání. Praha: Linde. 768 s. ISBN 978-80-7201-880-2.

Peak DMC \& Skift (2014). The Rise of Experiential Travel. [online]. Available from: http://skift.com/wp-content/uploads/2014/06/skift-peak-experiential-travelerreport1.pdf.

Petrick, J. F., \& Durko, A. M. (2015). Segmenting luxury cruise tourists based on their motivations. Tourism in Marine Environments, 10(3-4), pp. 149-157.

Pine, J. B. \& Gilmore, J. H. (1999). The experience economy: work is theatre \& every business a stage. Boston: Harvard Business School Press. 254 p. ISBN 0-87584-819-2.

Prague Daily Monitor. (2018). Number of Czech dollar millionaires increases to 28,140. [online]. Available from: http://praguemonitor.com/2018/07/10/number-czech-dollarmillionaires-increases-28140.

Radiant Insights. (2018). Luxury Travel Market Growth. [online]. Available from: https://www.prnewswire.com/news-releases/luxury-travel-market-growth-cagr-of-6-83size-statistics-key-trends-developments-and-opportunities-radiant-insights-inc-864393895.html.

Silverstein, M. J, Fiske, N., \& Butman, J. (2003). Trading up: The New American Luxury. New York: Portfolio, 316 p. ISBN 1591840139.

Uysal, M., \& Jurowski, C. (1994). Testing the push and pull factors. Annals of Tourism Research, 21(4), pp. 844-846.

Williams, S. \& A. Lew, A. A. (2014). Tourism geography: critical understandings of place, space and experience. Third edition. London: Routledge. 346 p. ISBN 041585444X.

World Tourism Forum. (2014). [online]. Available from: http://www.worldtourismforum.net/. Yoon, Y., \& Uysal, M. (2005). An examination of the effects of motivation and satisfaction on destination loyalty: a structural model. Tourism Management, 26(1), pp. 45-56. 